Covered in: ERIH PLUS, HeinOnline, CEEOL, Index Copernicus, CrossRef, CrossCheck, J-GATE, Google Scholar, Ideas RePeC, Econpapers, Socionet, KVK, WorldCat.

2018, Volume 6, Issue 1, pages: 31-36 | doi: https://doi.org/10.18662/lumenlaw/04

\section{Killing a Corpse - a Putative Crime}

\section{Mădălina-Elena TOMA1 \\ 1 "Stefan cel Mare" University, Suceava, Romania, e.madalina91@yahoo.co.uk}

\begin{abstract}
The article proposes a discussion about the institution of the putative deed. Since there is no explicit legal regulation, many discussions have existed and continue to exist in the specialized legal literature. We are, therefore, talking about a person who executes certain acts of execution with the intention of killing another person, without knowing that he was deceased before the moment of commencement of his activity. The article urges reflection on the importance of the intention to kill, executed against a corpse, in terms of danger to society.
\end{abstract}

Keywords: homicide, corpse, criminal offence, attempt.

How to cite: Toma, M.-E. (2018). Killing a Corpse - a Putative Crime. Logos Universality Mentality Education Novelty: Law, 6(1), 31-36. https://doi.org/10.18662/lumenlaw/04 


\section{Introduction}

The putative act is the deed committed by a person who, in the sense of his conscience, has the idea of committing an offense, although, in the reality surrounding us, that act is not prescribed by the criminal law, which means that it is not a crime. We are, therefore, talking about a misrepresentation of reality, an incorrect appraisal of it. For example, we can talk about a putative act if a person puts into circulation a currency he considers to be false, a coin that is in fact good.

Also a putative act is the one described in the title - killing a corpse. In the doctrine, there is ample debate on this subject, considering the hypothesis that a person is committing an act of execution specific to murder, but without having the representation that the person he is trying to kill is in fact deceased.

\section{2. "Killing a corpse"}

In the specialized doctrine, considering the situation we are referring to (the "killing" of a corpse), the main discussion about the connection of the deed with the crime of murder. Thus, two opposing opinions are distinguished: the first, according to which the person commits a putative act, therefore, he is not criminally liable; and the second, according to which there can be talked about the existence of a punitive attempt.

\subsection{Doctrinal opinions}

The first opinion is the most widespread in the doctrine. It is, therefore, discussed the existence of a putative fact that does not attract the criminal responsibility of the perpetrator, precisely because of the nonexistence of the crime type. The legal object of the crime of murder is the social relations related to the right to life, the fundamental value of society, whose normal course of action presupposes the protection of the person's life against "intentional acts of killing" (Cioclei, 2016, p. 10).

I must emphasize the idea that "the right to life is protected regardless of the victim's age, health status, etc. from the moment of birth to the moment of natural death" (Toader, T., Safta, M., 2015, p. 36). We are talking about protection offered to living people, so that once the person is no longer alive at some point (prior to an act of execution specific to murder), there can be no discussion of the existence of protected social value, nor about the existence of the object of the offense.

Also from the same point of view, the doctrine (Cioclei, 2016, p. 13; Constantin, 2016, p. 87), emphasizes that the passive subject of the offense 
provided by art. 188 of the Romanian Penal Code, namely murder, cannot be a corpse. Thus, the typical acts committed on the corpse could be described as crimes of profanation of corpses or graves (an offense under Article 383 of the Romanian Criminal Code).

Going on the idea of a possible criminalization of the act of "killing" a corpse, I note, first of all, that the Romanian legislator has stated the following: "The stealing, destruction or profanation of a corpse or ashes resulting from its incineration shall be punished by imprisonment from 6 months to 3 years" (Art. 383 (1) Romanian Criminal Code). It is, therefore, a crime designed to protect relationships of social cohabitation, whose normal development is closely linked to the defense of the collective sense of respect for human corpses (as well as the ashes resulting from the incineration of the corpses).

It is important to emphasize what is meant by "corpse" for the purposes of the present crime, so that the doctrine defines it as "the corporeal remnant of the deceased in any form whatsoever" (Grofu, 2016, p. 107). Of course, we are considering a comparative analysis of the crime of murder, since we started from the "killing" of a corpse, so that in order to criminalize the deed in accordance with art. 383 of the Romanian Criminal Code, but also to find us in the situation where the perpetrator believed that his victim was alive, the body should not show visible traces of disintegration. However, the premise of this crime lies in the existence of a human body, a requirement that is fulfilled by the hypothesis from which this article began.

The material element of the offense of corrupting corpses or graves is an alternative one: stealing, destruction, or profanation. What we are interested in is destruction, this being represented by "the destruction, the total or partial abolition of the corpse" (Grofu, 2016, p. 109).

An interesting and important aspect of this crime, the profanation of corpses or graves, we encounter in analyzing the subjective side, namely the subjective element. Thus, the latter implies the direct or indirect intent of the perpetrator. Therefore, committing this deed is not incriminated, therefore, it is not punishable.

Of course, speaking of an author who intends to kill a living person, who he does not know is dead, we are talking about an obvious intention. Still, we ask ourselves if we can still talk about intent if we talk about killing a corpse that was not known about this essential issue? The culpable may be invoked so that the perpetrator is not punished under art. 383 of the Romanian Criminal Code? 
The issue is even more questionable if we relate to an attempt. The Romanian legislature stated the following: "(1) The attempt consists in the execution of the intention to commit the offense, execution which was interrupted or not produced its effect. (2) There is no attempt when the impossibility of consuming the offense is the consequence of how execution was conceived." (Art. 32 Romanian Criminal Code).

There are opinions in the Romanian doctrine that argue that an attempt can be kept in the task of the perpetrator. In the view of the Romanian Criminal Code, the doctrine defines the attempt as "the attempt to commit a certain offense by passing on the execution of acts of execution, which, however, was not carried out, or, although it was finished, the production of the result and, therefore, the use of the offense did not take place” (Bulai, B., \& Bulai, N. 2015, pp. 31-32). The attempt is different from crime, therefore, in two respects: whether it is an incomplete execution or the non-production of the offense characteristic of the crime.

In the case of the "killing" of a corpse, we really talk about the nonproduction of the characteristic feature of the offense, because the passive subject in question is no longer the victim, the living person, but the state (the corpse already exists). An isolated opinion in Romanian criminal doctrine is that the perpetrator could respond for a punitive attempt. This idea is based on arguments related to the psychic attitude of the perpetrator, an essential and important element, as he knows that the act he is committing is an offense under the criminal law and, moreover, with that representation, he does the deed.

\section{The danger behind the intention to kill}

From my point of view, the danger to protected social values is real, as the perpetrator would not hesitate to move the acts of execution if he faced a living person; or the mere chance of doing these acts on a corpse he does not know about and considers him an animated body is not able to remove danger or guilt. As for the fact that there is no life at the time of "killing" the corpse, that is precisely why the crime of murder remains at the trial stage and prevents the offense from being consumed; Conversely, if it were an animated victim, the attempt would not have existed, and we could have discussed about a murder offense.

In favor of this view, states such as France or Germany, through the courts, issued convictions for persons who attempted the murder offense in the case of execution of actions that were capable of producing death if they were have been committed on a living person, although they have been applied to a corpse. 
Moreover, I emphasize that there are two conditions that have to be fulfilled cumulatively for the existence of the attempt: to have the intention of the perpetrator to commit a certain offense, namely the execution to be interrupted or not to have produced the result. From this point of view, the perpetrator does both, since the intention to commit murder exists in the mind of the perpetrator, the desire to commit the offense, which is followed by the execution of his intention.

Of course, the question of the typical nature of the act must also be considered, since the provisions of art. 32 of the Romanian Criminal Code reveals the necessity of enforcement of the intention to commit an offense, or this presupposes to be in the presence of a criminal act. Since the perpetrator enforces acts on a deceased person, but which he considers alive, we are in the situation of not discussing a typical act, nor, therefore, an attempt.

\section{Conclusions}

Taking into account all the above detailed aspects, committing such a putative act (the "killing" of a corpse) presents a social danger that should be prevented, from my point of view. Current legislation allows the perpetrator to "slip" and not be penalized, although the intention to kill is real and enforced. Even if the acts of execution are made in the face of a corpse, or the passive subject of the crime of murder may be just a living person, the more the perpetrator's desire to kill a person he believes in life should raise a question mark.

\section{References}

Art. 32 Romanian Criminal Code

Art. 383 (1) Romanian Criminal Code

Bulai, B., \& Bulai, N. (2015). "Explicațiile noului Cod penal" Vol. I - coordinated by Antoniu, G. and Toader,T. Bucharest: Universul Juridic Publishing House.

Cioclei, V. (2016). Drept penal. Partea specială. Vol. I, C. H. Bucharest: Beck Publishing House

Constantin, E (2016). Infracțiunile contra vieții în noul Cod penal. Bucharest: Universul Juridic Publishing House, Bucharest.

Grofu, N. (2016). Explicatiile noului Cod penal. Vol. V - coordinated by Antoniu G. Tudorel and Toader, T. Bucharest: Universul Juridic Publishing House, Bucharest. 
Killing a Corpse - a Putative Crime

Mădălina-Elena TOMA

Toader, T., Safta, M. (2015). Explicatiile noului Cod penal. Coordinated by Antoniu G. Tudorel and Toader, T, Vol. III, Bucharest: Universul Juridic Publishing House. 